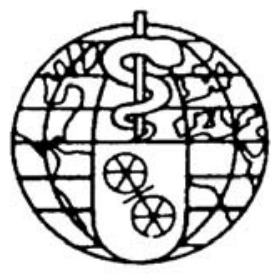

WORLD ASSOCIATION FOR DISASTER AND EMERGENCY MEDICINE

EDUCATION COMMITTEE WORKING GROUP

$30^{\text {th }}$ July 2004

\title{
International Standards and Guidelines on Education and Training for the Multi-disciplinary Health Response to Major Events which Threaten the Health Status of a Community
}

\section{An Issues Paper}

This Issues Paper is published with the permission of the President of the World Association for Disaster and Emergency Medicine. JEPHC thanks Dr. Knut Sundnes for allowing JEPHC to publish this paper of international significance.

Readers will note reference to an invitation for submissions in response to the Issues Paper and should not be distracted by the dates listed in the Issues Paper and are encouraged to forward any comments directly to $\underline{\text { Dr. Geert Synaeve. }}$

This issues paper is the result of an initiative launched by WADEM during the 13th WCDEM in Melbourne 2003. It is being concurrently published on the WADEM website at http://wadem.medicine.wisc.edu/ and in JEPHC. A short version is also available on the WADEM website and also published in WADEM's journal "Prehospital and Disaster Medicine" Volume 19, No. 2, 2004.

\author{
Writing Team, \\ on behalf of the Working Group: \\ Dr. Geert Seynaeve (Belgium) - Chair \\ A/Prof. Frank Archer (Australia) - Editor of Issues Paper \\ Dr. Judith Fisher (UK/USA) \\ A/Prof Brigitte Lueger-Schuster (Austria) \\ Dr. Alison Rowlands (UK) \\ Mr Phillip Sellwood (UK) \\ Dr. Karel Vandevelde (Belgium) \\ Dr. Anastasia Zigoura (Greece)
}




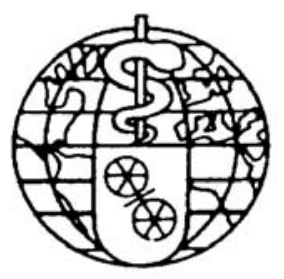

WORLD ASSOCIATION FOR DISASTER AND EMERGENCY MEDICINE

EDUCATION COMMITTEE WORKING GROUP

$30^{\text {th }}$ July, 2004

\section{International Standards and Guidelines on Education and Training for the Multi-disciplinary Health Response to Major Events which Threaten the Health Status of a Community}

\section{Invitation}

The $13^{\text {th }}$ World Congress on Disaster and Emergency Medicine, held in Melbourne, Australia, in May 2003, requested the World Association for Disaster and Emergency Medicine (WADEM) to lead the development of "International Standards and Guidelines on Education and Training for "Disaster Medicine". This Paper has been developed by a Working Group of the WADEM Education Committee (the Working Group) in response to that request from the international "Disaster Medicine" and emergency health community.

The Working Group recognises that the definition of "Disaster Medicine" is dynamic and currently lacks international consensus. For the purposes of this Paper, "Disaster Medicine" should be interpreted in a generic and inclusive sense. The contemporary view is that of a multi-disciplinary health response to major events which threaten the health status of a community, including the prevention and mitigation of future events, and taking account of the broader context in which these events occur.

On behalf of the Working Group, we invite you, as a member of the "Disaster Medicine" and emergency health community, to participate in the following international consultation to consider issues of education and training in "Disaster Medicine" and major incident management. The first stage of this process is that we would like you to respond with comments, to the issues raised in the attached paper, in the format and timeframe as outlined below:

- $\quad$ Name and title, institution and position of principal respondent

- $\quad$ Contact details of principal respondent - email, normal mail, phone, fax

- $\quad$ Issue to which you are responding: number and title (please address as many issues as you wish, but please clearly link each issue, and your specific response to that issue)

Your responses should be emailed to the Chair of the Working Group, Dr Geert Seynaeve at : fa082693@skynet.be and the deadline for response is 17 ${ }^{\text {th }}$ September, 2004.

The next phase will be an international meeting to provide a forum to further debate the issues. Details of the meeting to be held in Brussels over $29^{\text {th }}-31^{\text {st }}$ October, 2004 can be found at : http://www.ecomed.be/conference.htm .

The results of the consultation will lead to the development of international standards and guidelines that will be presented at the $14^{\text {th }}$ WCDEM, to be held in Edinburgh in May, 2005 for endorsement.

Frank Archer

For WCDEM-13
Geert Seynaeve Chair of Working Group
Alison Rowlands Organising Committee for October meeting 


\subsection{INTRODUCTION \\ 1.1 Purpose}

The main focus of the Working Group is to develop standards and guidelines for education and training in the multi-disciplinary health response to major events which threaten the health status of a community.

It is the vision of the Working Group that evidence based standards and guidelines for education and training need to be developed in a broad sense, for all members of the health care community. Rather than purely describing isolated performance indicators, the Working Group agreed that priority be given to explaining the general approach, presenting the conceptual framework, clarifying important principles, and describing the educational needs and training requirements for situations where there exists a major threat to the health status of a community.

It is not the intent to produce an updated educational curriculum for special courses in "Disaster Medicine" by listing levels of theoretical knowledge and clinical skills required for medical doctors, nurses, and paramedics. Nor does the Working Group think it is useful to repeat requirements and learning outcomes which are part of the normal basic education and training for the various health professionals.

The purpose of this Issues Paper is to present an initial summary of current issues relating to an international perspective of "Disaster Medicine” education and training. This summary has been prepared following discussions within the Working Group of the WADEM Education Committee. (Appendix 1).

The paper aims to stimulate debate and form the basis of further discussion at an international meeting scheduled to be held in Brussels (Belgium) on $29^{\text {th }}-31^{\text {st }}$ October, 2004, the details of which can be found at the following web site: http://www.ecomed.be/conference.htm .

This Issues Paper is being circulated to members of WADEM, particularly to participants of the Education meeting at the WCDEM-13 held in Melbourne in May 2003, and to a wide cross section of the international "Disaster Medicine" and associated community, and, targeted individuals and groups. The Working Group invites your response to this Issues Paper. Responses should be forwarded to Dr Geert Seynaeve by email at: fa082693@skynet.be by the deadline for response of $\mathbf{1 7}^{\text {th }}$ September 2004.

\subsection{Disclaimer}

The contents of this Issues Paper have been prepared in good faith to stimulate discussion, critical reflection and independent input. To the best of our knowledge, it doesn't contain copyright or privileged material unless so identified in the text. The views expressed do not necessarily reflect the views of WADEM, the Working Group, or individual members of the Working Group.

\subsection{Acknowledgements}

The Working Group wishes to acknowledge the support provided by the hosts and their staff at each of the Brussels, Barcelona, Athens and Edinburgh meetings. In particular, the Working Group acknowledges support from the WADEM International Memberships, Committees and Task Forces secretariat, ECOMED and the European Society for Disaster Medicine. 


\subsection{SUMMARY OF KEY ISSUES}

The Working Group has structured the Issues Paper in 5 parts and has identified several key issues for discussion. These are summarised below:

\section{PART 1:}

Understanding the contemporary interpretation of the multi-disciplinary health response to major events which threaten the health status of a community.

Issue 1: Definitions and terminology in "Disaster Medicine";

$>$ Issue 2: Getting to grips with the contemporary concepts and international trends in "Disaster Medicine"; and,

$>$ Issue 3: Valuing personal attributes in "Disaster Medicine” practitioners.

\section{PART 2:}

Developing an underlying scientific framework for linking theory to practice in "Disaster Medicine".

$>$ Issue 4: Creating a scientific framework(s) for "Disaster Medicine”.

\section{PART 3:}

Defining a conceptual framework and general principals to develop "International Standards and Guidelines on Education and Training for the Multi-disciplinary Health Response to Major Events which Threaten the Health Status of a Community"

$>$ Issue 5: WHERE ARE WE NOW? - Getting to grips with the contemporary concepts and international trends in "Disaster Medicine" education and training.

$>$ Issue 6: WHERE DO WE WANT TO GET TO? - Identifying contemporary evidence-based education and training standards and guidelines for "Disaster Medicine” education and training programs.

$>$ Issue 7: HOW DO WE GET THERE? - Overcoming barriers to introducing the International Standards and Guidelines.

PART 4:

Maintaining the momentum - improving international collaboration.

Issue 8: Exploring the feasibility of an ongoing, international, collaborative network of "Centres of Excellence" in "Disaster Medicine" research and/or education.

\section{PART 5:}

Additional input.

Issue 9: What other issues would you like to bring to the attention of the Working Group? 


\section{UNDERSTANDING THE CONTEMPORARY INTERPRETATION OF THE MULTI-DISCIPLINARY HEALTH RESPONSE TO MAJOR EVENTS WHICH THREATEN THE HEALTH STATUS OF A COMMUNITY.}

The Working Group suggests there is a need to understand the contemporary interpretation of the health response to "disasters", as the evidence-base to support informed, relevant and dynamic education and training programs of the future.

\subsection{ISSUE 1: Definitions and terminology in "Disaster Medicine".}

\subsubsection{Definitions of "Disasters" and "Disaster Medicine"}

Al-Madhari and Keller, in their 1997 review of disaster definitions, identified 27 definitions which had "disruption to the infrastructure in a community" as a common theme, and concluded that "it was not feasible to formulate a universally acceptable definition of disaster that will satisfy all practitioners". (Al-Madhari AF, Keller AZ: Review of Disaster Definitions. Prehospital and Disaster Medicine 1997;12(1):17-21 http://pdm.medicine.wisc.edu ).

The WHO provides a generic definition of a "disaster": "the result of a vast ecological breakdown in the relationships between man and his environment, a serious and sudden (or slow, as in drought) disruption on such a scale that the stricken community needs extraordinary efforts to cope with it, often with outside help or international aid”. (Sundnes KO, Birnbaum ML, Eds: Health Disaster Management Guidelines for Evaluation and Research in the Utstein Style. Prehospital and Disaster Medicine 2003;17(Suppl 3):p32 http://pdm.medicine.wisc.edu ).

Another approach is through the eyes of epidemiology. The Centre for Research on the Epidemiology of Disasters (CRED) is a WHO Collaborating Centre and based at the School of Public Health, Catholic University of Louvain, Brussels, Belgium. CRED defines a "Disaster" as: "a situation or event which overwhelms local capacity, necessitating a request to national or international level for external assistance.” However, CRED requires the event to meet one of the following criteria: ten or more people reported killed; 100 people reported affected; a call for international assistance; and/or declaration of a state of emergency. (http://www.em-dat.net/disasters/sundata/wdr/wdr2002.htm)

The Working Group believes that these definitions, although useful in their context, do not adequately reflect contemporary perspectives, and that there needs to be a consensus, even if it is descriptive, on definitions if there is to be effective international, scientific and educational communication.

\section{ISSUE 1.1 - Definitions of "Disaster” and of "Disaster Medicine”}

The Working Group has identified "Definitions” as an issue and seeks input on:

$>$ contemporary international definitions of "Disaster" and of "Disaster Medicine”; and

$>$ suggestions for clarifying these definitions, particularly from the perspectives of health issues related to major events. 


\subsubsection{Terminology of "Disasters" and of "Disaster Medicine"}

The Working Group recognises that despite previous attempts to find international agreement on terminology in this dynamic field, there is currently either a lack of consensus on terminology, or the current "Standard Definition Sets" are not well known. In addition, the Working Group also believes that these "Standard Definition Sets", although useful in their context, are not adequately inclusive of contemporary perspectives.

WADEM’s Utstein Template http://wadem.medicine.wisc.edu/ and Gunn’s Dictionary of "Disaster Medicine”, (Gunn SWA; Multilingual Dictionary of Disaster Medicine and International Relief. Boston: Kluwer Academic publishers) currently provide recognised international examples of terminology in this field. Ultimately, the Working Group will need to refer to an international "Standard Definition Set".

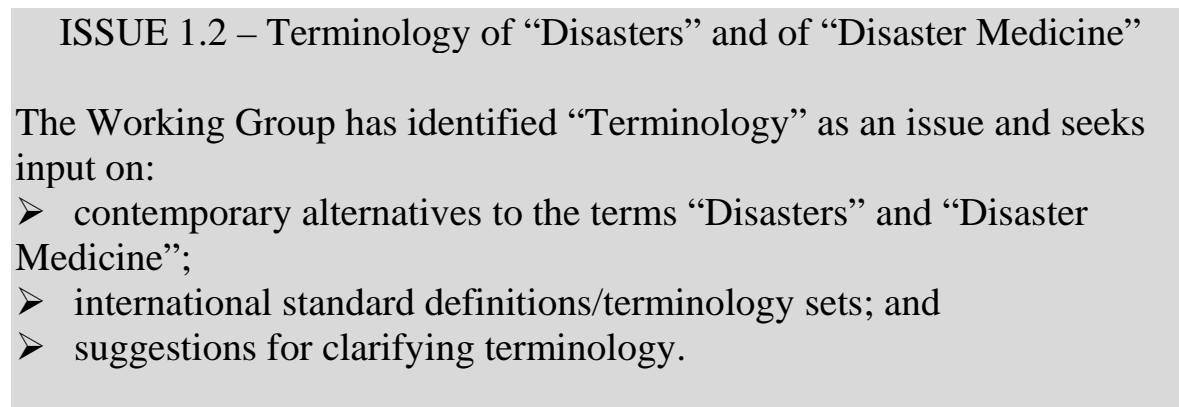

\subsection{ISSUE 2: Getting to grips with the contemporary concepts and international trends in "Disaster Medicine".}

The Working Group suggests there is a need to understand the contemporary interpretation of the health response to "disasters", in terms of:

o the scope (classifications) of "Disaster Medicine";

o contemporary concepts \& principles;

o emerging influences \& drivers;

o conceptual frameworks for understanding "Disaster Medicine”;

o the literature on the epidemiology and the science of "Disaster Medicine";

o learning from case studies of recent "Major Events"; and

0 the implications of having to maintain normal functions whilst also managing the "extraordinary event”?

\subsubsection{Scope (classifications) of "Disaster Medicine"}

The Working Group believes it would be useful to update and define the scope or field, of "Disaster Medicine". The scope of "Disaster Medicine" is often based on the classification of "Disaster” events. WADEM's Utstein Template http://wadem.medicine.wisc.edu/ currently provides a recognised international classification of disaster events. However, there are other classifications. There are a number of international data-bases of "Disaster" events which are based on various classification systems. However, these differ and there doesn't appear to be an internationally agreed scope (classification) of "Disaster" events. 
For example, the World Disasters Report lists the following types of disasters:

o Natural disasters, eg. droughts, floods, storms, etc;

o Non-natural disasters, eg. chemical spills, explosions, radiation leaks, transport accidents, etc., sometimes called, technologically disasters or manmade disasters, but doesn't include conflict.

(Ref. http://www.ifrc.org/publicat/wdr2002/chapter1.asp )

On the other hand, the CRED classification includes:

o Natural disasters;

o Technological disasters, and

o Complex emergencies

(Ref. http://www.em-dat.net/disasters/sundata/wdr/wdr2002.htm)

The more traditional classification of 'disasters' would include natural disasters, technological disasters, major incidents, and mass gatherings. The more contemporary classifications also include complex emergencies, and more recently, "public health crises”.

A recent overview of the scope and nature of complex emergencies is provided in a special issue of Prehospital and Disaster Medicine edited by Frederick M Burkle ( Burkle FM Ed, Special issue: Complex Emergencies: Prehospital and Disaster Medicine 2001;16(4) http://pdm.medicine.wisc.edu )

The concept of public health crises has been outlined by Geert Seynaeve. Seynaeve defines a public health crisis as "a situation where there is a (actual/potential) risk of a major exposure to an unusual serious health hazard for a community (for which is perceived as such). Rather than an acute disproportion between these and resources, a public health crisis is characterised by: inadequate information; scientific uncertainty, and/or public worry about causes, character, or dimensions of an unusual health problem. (Powerpoint Presentation available from Dr Geert Seynaeve at fa082693@skynet.be)

Some examples of public health crises would include infectious diseases, eg. SARS, Meningococcal disease, food contamination, NBCR “terrorism”, eg anthrax.

These contemporary inclusions in the classification of 'disasters' introduce the varying terminologies of "mass emergency management”, "emergency public health”, and "emergency health". This recent focus on "Public Health" in the scope of "Disaster Medicine" is also included in the "Melbourne Statement" endorsed at the conclusion of WCDEM-13 in Melbourne in May, 2003. (Appendix 2)

Also, there are significant regional differences in the profile of "disasters" around the globe. These are graphically demonstrated by CRED. (http://www.em-dat.net/disasters/sundata/wdr/wdr2002.htm). The implication for this Working Group as it develops international standards and guidelines for "Disaster Medicine” education and training, is that education and training programs must include principles based on a global perspective of these major events, whilst allowing flexibility to reflect local circumstances. 
Thus, the Working Group asks if the following list adequately represents a contemporary scope (classification) of major events which may threaten the health status of a community:

o Mass gatherings;

o Major incidents;

o Technological disasters;

o Natural disasters;

o Public health crises;

o Complex humanitarian emergencies.

Ultimately, the Working Group will need to adopt an internationally agreed scope (classification) of "Disasters" and of "Disaster Medicine".

\section{ISSUE 2.1 - Scope (classifications) of "Disasters" and of "Disaster Medicine"}

The Working Group has identified the "scope (classification) of

'Disasters' and of “"Disaster Medicine”," as an issue and seeks input on:

$>$ international classifications of "Disaster" events;

$>$ data-bases of "Disaster" events;

$>$ descriptions, and their basis, of the scope of "Disaster Medicine"; and

$>$ suggestions for clarifying the scope (classification) of "Disaster

Medicine”.

\subsubsection{Contemporary concepts and principles}

Most current “Disaster Medicine” practitioners and educators would underpin their practices with concepts and principles; however, these may not be explicit nor shared widely. The few text books on "Disaster Medicine" are variable in using an approach based on "concepts and principles". Likewise, the few journals devoted to "Disaster Medicine" and the "Disaster Medicine" articles in general journals, address concepts and principles in a fragmented manner.

As a consequence of the more contemporary classification of "disasters" as noted above, there is an emerging range of major concepts and principles which are evolving and as yet poorly defined in their application or role in "Disaster Medicine". For example:

o Surveillance, emergency preparedness, and the definition of competencies for all Public Health Workers, in the setting of Bioterrorism and Emergency Readiness (http://www.nursing.hs.columbia.edu/institute-centers/chphsr/btcomps.html)

o Changes to major incident procedures (Major Incident Procedure Manual, London Emergency Services Liaison Panel, $6{ }^{\text {th }}$ Edition, Metropolitan Police Service)

o Communicating with the public in a public health crisis, yet how poorly this is understood. http://www.sussex.ac.uk/press_office/media/media358.shtml

o Psycho-social support in situations of mass emergency (Seynaeve GJR (Edit). Psycho-Social support in situations of mass emergency. A European policy paper concerning different aspects of psychological support and social accompaniment for people involved in major accidents and disasters. Ministry of Public Health, Brussels, Belgium, 2001, 42 pages plus annexes ISBN:D/2001/9387/1). 
Of particular note in this evolution is the emergence of a risk management and proactive approach to "Disasters" and "Disaster Medicine”. Arnold, in examining this paradigm for "Disaster Medicine" in the $21^{\text {st }}$ Century, notes that "the future will depend on the clearest possible understanding of the root causes of disasters" and suggests that "risk assessment is the bridge that will take us from the post disaster improvisation of the past to the pre-disaster preparedness of the future". (Arnold JL, "Disaster Medicine" in the $21^{\text {st }}$ Century: Future Hazards, Vulnerabilities and Risk. Prehospital and Disaster Medicine. 2002:17(1); 3-11 http://pdm.medicine.wisc.edu.

Other authors are also writing in the same direction as Arnold, for example:

0 Britton, who questions the contemporary relevance of the "Prevention, Preparedness, Response, and, Recovery” approach to managing emergencies and disasters. (Britton NR. A New Emergency Management for the New Millennium? Aust J of Emerg Management, Summer 2001-2002, P44-54); and

o The World Disasters Report, published by the International Federation of Red Cross and Red Crescent Societies, which also promotes the risk management paradigm http://www.ifrc.org/publicat/wdr2002/index.asp.

These examples are not intended to be comprehensive, but are included to indicate that "change is in the wind". The Working Group believes that there is a pressing need to collate the current concepts and principles which provide the base for the future practice of "Disaster Medicine" and its education and training programs.

\section{ISSUE 2.2 - Contemporary concepts and principles}

The Working Group has identified defining “contemporary concepts and principles" in "Disaster Medicine" as an issue and seeks input on:

generally accepted concepts and principles which provide the base for the current practice of "Disaster Medicine", are international and should be confirmed as reasonable current practice;

concepts and principles which are historical remnants and should be relegated to history;

the gaps in concepts and principles which should be updated to reflect current practices; and

suggestions for clarifying concepts and principles.

\subsubsection{Emerging influences and drivers}

The Working Group has also identified that there are a number of emerging influences and drivers for change in "Disaster Medicine". Understanding these contemporary factors is a requirement if education and training programs are to not only be contemporary but also lay the base for the "graduate" to be able to adapt to change in the immediate future. This is a major challenge for the International Disaster Medicine and Emergency Health Community!

The Working Group has identified that there are a number of current drivers for change and some contemporary/emerging issues in "Disaster Medicine", including but not limited to the following: 
o Geo-political issues;

o A change in focus from natural disasters to other types of events, eg. major accidents, complex humanitarian emergencies, violence/war/terrorism related issues, man-generated, unresolved/ongoing events;

o Introduction of the concept of "Public health crisis";

o Changing nature of major incidents, major accidents and disasters in their presentation and management;

o The rapid "evolution" of the concept of "emergency preparedness";

o The "Melbourne Statement" (Appendix 2) which sought to increase the Public Health context in "Disaster Medicine", and emphasised the importance of the psycho-social and health social science perspectives, which is consistent with the European Framework on the psycho-social aspects of mass emergencies and with the trend in the literature from "Disaster Medicine" to "health response to threats to health" or "emergency (public) health";

o The emphasis on the community level of response and support in disasters, rather than relying on "experts" and "foreign aid", ie. mutual assistance;

o The necessity of integrating the response during the immediate impact phase with the follow up of long term health consequences, and with ongoing processes of evaluation and feedback, which have an influence on prevention, litigation and preparedness of future events.

The Working Group believes that these may or may not be an accurate reflection of contemporary/emerging practice. However, it believes that there is "change in the wind" and that this change needs to be described as a precursor to developing effective education and training programs to underpin the effective health response to disasters. At this time, the Working Group believes that this "change” is not well articulated in the literature. To further clarify this issue, the Working Group is supporting the preparation of a "White Paper" which will provide more detailed background information on specific health emergencies, including case reports and thematic reference articles. Contributions to the proposed "White Paper" are listed as Background Papers in Para. 3.2.5 of this Issues Paper.

\section{ISSUE 2.3 - Emerging influences and drivers}

The Working Group has identified "emerging influences and drivers” of "Disaster Medicine" as an issue and seeks input on:

$>$ emerging influences and drivers impacting on the international practice of "Disaster Medicine"; and suggestions for clarifying emerging influences and drivers.

\subsubsection{Conceptual frameworks for understanding "Disaster Medicine"}

Conceptual frameworks to describe and/or understand "Disaster Medicine" are a keystone for effective communication, to advance the science of "Disaster Medicine" and to underpin education and training programs. The Working Group is keen to receive input on conceptual frameworks that are in use around the world and to then identify those that represent "Best Practice". 
The Working Group has explored the consequences of moving the paradigm of "Disaster Medicine" to a more contemporary paradigm of the "health response to events that are a major threat to the health of a community" and lament the lack of conceptual models from this perspective.

The Working Group was advised of a conceptual model recently published by Bradt, Abraham, and Franks (1), which provided a valuable starting point for discussions on conceptual frameworks and which also proved useful when considering the educational perspectives of "Disaster Medicine".

Any conceptual model will need to be refined and described in more detail by making use of the epidemiology and scientific literature, and best practice based on lessons learned, each of which will be raised in subsequent Issues.

The model of Bradt, Abraham, and Franks is outlined in the following diagram:

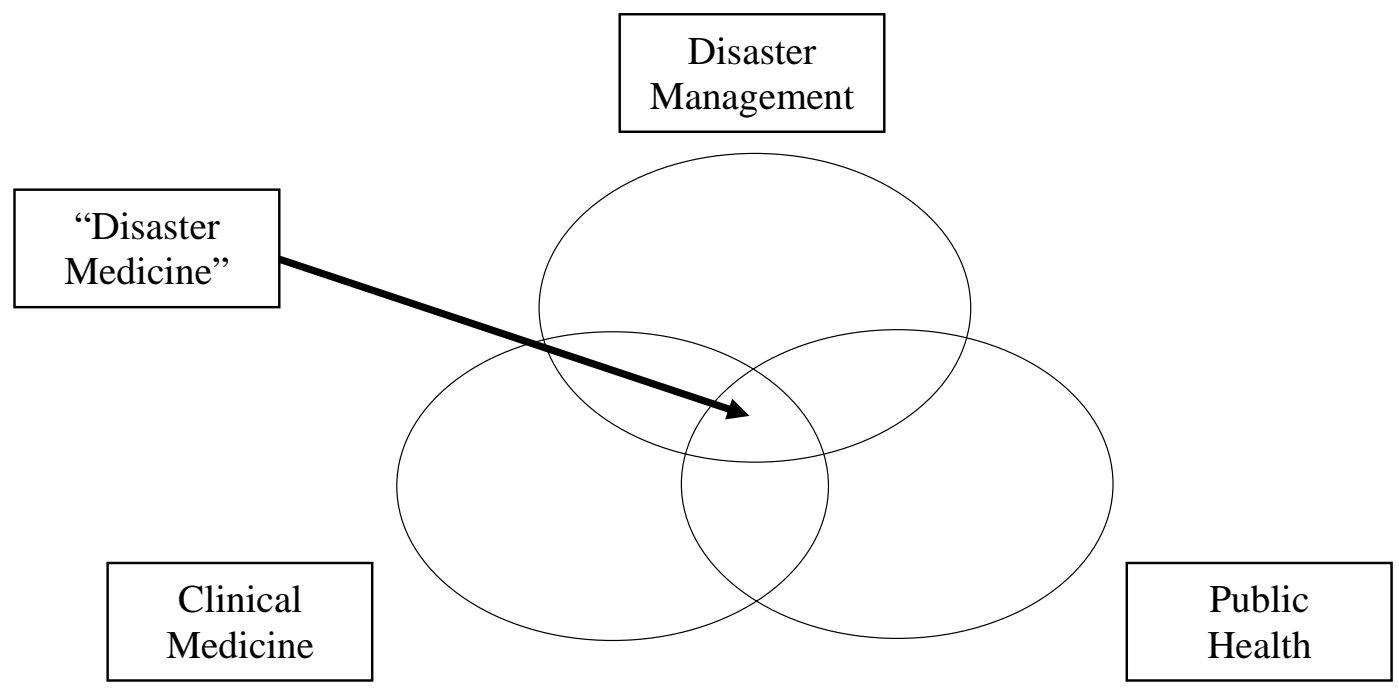

"Disaster Medicne" is seen to be at the intersection of the three disciplines of: clinical medicine, disaster management, and, public health.

The Working Group expanded the three “disciplines” to be more inclusive, eg:

o "clinical medicine", was interpreted to be inclusive of all clinical disciplines, ie medicine, nursing, paramedics, psycho-social etc;

o “disaster management”, was interpreted to represent all phases of "major events that were actually or potentially a threat to the health status of a community", and included a "risk management" approach; and

o “public health", was interpreted to include all perspectives of public health that may relate to "major events that were actually or potentially a threat to the health status of a community", eg, disease monitoring, infection control, epidemiology etc.

\footnotetext{
${ }^{1}$ Bradt D, Abraham K, and Franks R, A Strategic plan for Disaster Medicine in Australasia. Emergency Medicine (2003) 15, 271-282
} 
The Working Group believes that this most useful model requires to be underpinned by features such as:

0 an academic base, including research, evidence-based standards and guidelines, and the principles of international health;

o quality processes;

0 credentialing of graduates; and

o external accreditation of education programs.

The Working Group applied this model to various scenarios as a framework to analyse the health issues and believes that the model can be usefully applied in this manner.

Whilst this model proved valuable in the Working Group's discussions, it may not be the only appropriate model, nor may it adequately describe the contemporary perspectives of "Disaster Medicine". Thus the Working Group seeks input on other models and approaches to help describe and understand a contemporary view of "Disaster Medicine".

ISSUE 2.4 - Conceptual frameworks for "Disaster Medicine”

The Working Group has identified conceptual frameworks in "Disaster Medicine" as an issue and seeks input on:

$>$ conceptual frameworks that may be suitable to describe and understand the current or emerging international practice of "Disaster Medicine"; and

$>$ suggestions for clarifying or developing contemporary conceptual frameworks.

\subsubsection{The literature on the epidemiology and the science of "Disaster Medicine"} The Working Group believes that it should take an evidence-based approach to its tasks. The Working Group recognises the importance of exchanging and discussing experiences and knowledge about major incidents, internationally, and across professional disciplines. The Working Group will sponsor initiatives or publications which make available (peer reviewed) information, keynote articles, and relevant data with a view to improving the management of health emergencies and crises.

In order to identify the current status of the scientific literature, and more particularly of the epidemiology of major incidents, the Working Group will seek invited colleagues to undertake specific reviews of the literature as outlined below. The aim is to collect and explicitly describe the sources and references that will be used as the basis for later discussion on best practice and educational standards in "Disaster Medicine”.

Four references, three already cited, provide an insight to the epidemiology of disasters and emergencies at an international level:

o Sundnes KO, Birnbaum ML, Eds: Health Disaster Management Guidelines for Evaluation and Research in the Utstein Style. Prehospital and Disaster Medicine 2003;17(Suppl 3):p32 http://pdm.medicine.wisc.edu - provides a general overview. 
o The World Disasters Report (2002), published by the International Federation of Red Cross and Red Crescent Societies http://www.ifrc.org/publicat/wdr2002/index.asp - provides a comprehensive case study type review of selected, recent major events, primarily from the humanitarian perspective;

o The World Disasters Report (2003), not cited above, http://www.ifrc.org/publicat/wdr2003/contents.asp - provides disaster data, key trends and statistics, mainly from 1993 to 2002.

o The Centre for Research on the Epidemiology of Disasters (CRED). http://www.em-dat.net/disasters/sundata/wdr/wdr2002.htm - provides a comprehensive data resource, presented in tables and graphs from a global perspective, of major events from 1900 to the present time.

These various sources, whilst valuable, also have their limitations. However, they provide "best available" evidence to inform discussion. There are other sources of disaster databases, eg.

$\mathrm{o}$ in the UK, BASICS has an extensive database of disasters http://www.basedn.freeserve.co.uk/,

o in Australia, Emergency Management Australia also provides a web-based database of disasters http://www.ema.gov.au/ema/emaDisasters.nsf

One emerging international tool which will facilitate the evidence-base of health disaster management in the future is the recently published "Health Disaster Management: Guidelines for Evaluation and Research in the Utstein Style” published as a supplement to Prehospital and Disaster Medicine, Vol. 17, 2003 (http://pdm.medicine.wisc.edu ).

\section{Invited Background Papers:}

To further clarify this issue the Working Group invites the preparation of a range of "Background Papers", namely;

o The historical context of "Disasters" and "Disaster Medicine”, and their influences on contemporary "Disaster Medicine";

o Identification of international bodies leading “Disaster Medicine”, their roles and relationships;

o Identifying the range of disciplines involved in "Disaster Medicine";

o Identification of current Centres of "Disaster Medicine” Research, including available resources;

o Summaries of Epidemiology reports of "Disasters": eg World Disasters Report, Data-bases/Registries of "Disasters", Epidemiological Literature; o A meta-analysis of systematic reviews in "Disaster Medicine", including a search of the Cochrane Library;

o A systematic review of the evidence base in the peer reviewed literature;

o Annotated bibliography of Government/Organisation Reports, Standards and Guidelines;

o A review of the non-peer reviewed literature (as far as is feasible);

o Identification of comparable approaches/programs in kindred disciplines: eg. International Liaison Committee on Resuscitation, Standards and Guidelines for professional courses, potentially with an international perspective, which could be used as models for this Working Group to develop International Standards and Guidelines. 
ISSUE 2.5 - Literature on the epidemiology and the science of 'Disaster Medicine'

Whilst the Working Group will be inviting input on these specific approaches to the literature, the Working Group also believes that the international disaster medicine and emergency health community is so rich and diverse that there will be individuals and groups who will have already prepared papers addressing some of the above in total or in part.

The Working Group invites you to supplement the invited papers and to identify current Centres of "Disaster Medicine” research, including available resources and illustrative case histories.

The Working Group also wishes to receive suggestions on priorities for future research and action.

From these reviews, the Working Group will also provide input to the WADEM Research Committee to assist that Committee in its tasks, one of which is the development of a future research and action priorities in "Disaster Medicine”.

\subsubsection{Learning from case studies of recent "Major Events"}

The annual publication of the World Disasters Report typically includes a number of case studies which are used as examples to illuminate various aspects of "Disasters"

o 2002 - http://www.ifrc.org/publicat/wdr2002/index.asp

o 2003 - http://www.ifrc.org/publicat/wdr2003/contents.asp

Other international organisations also provide a rich source of disaster epidemiology and case studies information, eg.:

o WHO - http://www.who.int/en

o WHO: Relief Web - http://www.reliefweb.int/w/rwb.nsf

o PAHO - http://www.paho.org/default.htm

o UN - IRIN - http://www.irinnews.org

There are no doubt other valuable resources of a similar nature.

The Working Group believes that this style of analysis and presentation is a powerful adjunct to the more traditional quantitative approach to disaster reports and has great potential to assist the international disaster medicine and emergency health community to understand many aspects of "Disasters" and "Disaster Medicine”. It also believes that this style has great potential to assist learning in "Disaster Medicine” education and training programs.

Towards these ends, the Working Group invites case study type input to help define the parameters and aid understanding of one or more aspects of "Disasters" and "Disaster Medicine", and/or, to be used as exemplars for education and training programs in this field. 
The Working Group believes in the value added nature of case studies to aid understanding aspects of "Disasters", "Disaster Medicine” and/or "Disaster Medicine" education.

The Working Group seeks input on your experiences reflected through case studies to illuminate understanding of one or more aspects of "Disasters”, "Disaster Medicine” and/or "Disaster Medicine” education.

\subsubsection{The implications of having to maintain normal functions whilst also managing the extraordinary event.}

The Working Group is acutely aware that one of the significant implications of managing extraordinary events which are a threat to the health status of the community, is the maintenance of normal functions both within the community and by the emergency services. The Working Group believes that this adds an additional paradigm for both understanding the management of these events, and also for education and training.

The Working Group believes that the management of major accidents, disasters and other extraordinary health emergencies should be based on a well prepared mobilisation and reorganisation of the usual health services and agencies which have the resources, skills, knowledge, and experience to deal on a daily and routine basis with individual emergencies or small scale incidents.

Education and training, response planning and exercises are a part of the necessary core preparedness for situations of mass emergency of the usual emergency medical services, ie. call taking, dispatching, ambulance, prehospital medical teams, accident and emergency departments. Emergency professionals who respond to an industrial accident also require the collaboration and information of the occupational health and safety officials who are responsible for the daily issues of industrial safety and prevention in an enterprise.

Furthermore, routine screening, monitoring, and early warning systems used for daily surveillance of communicable diseases are essential in order to be able to manage a major infectious outbreak or to detect clusters of unusual health symptoms/syndromes.

According to the unfolding scenario, the typology and circumstances of a specific major incident, these routine health services and agencies will need to be complemented and/or reinforced by adequate and timely mobilised extraordinary resources, specialist expertise and supplies.

An adequate management of disasters raises the issue of the relation between daily routine health services and extra ordinary needs for situations. It is also a question of proportions and priorities and it is a challenge to find an adequate balance with respect to exceptional measures and principles, reserve stocks, and supplies, etc. 


\section{ISSUE 2.7 - Maintaining normal functions, while managing extraordinary events?}

The Working Group invites input on effective management strategies to maintain daily routine health services while managing unusual or extraordinary events.

The Working Group also invites input on the educational and training needs to underpin these management strategies.

\subsection{ISSUE 3: Valuing personal attributes in "Disaster Medicine" practitioners.}

The Working Group recognises that there is increasing acknowledgement that personal attributes and values are important in the practice of "Disaster Medicine" and hence need to be included in education and training programs.

During discussions, the following have been mentioned:

o Ethical, Legal, Religious, and Cultural Issues;

o Professionalism Issues, including coping with uncertainty;

o Evaluation and performance indicators, efficacy and efficiency;

o Decision making, information management, and cognitive processes;

o Collaboration, integration and teamwork; communication and interpersonal skills;

o Risk and vulnerability issues, perception and acceptability of risks, the precautionary principle; and

o Public relations, accountability, information and the right to know.

The 2003 publication of the World Disasters Report includes a number of case studies which could be used as examples to specifically illuminate some aspects of this issue http://www.ifrc.org/publicat/wdr2003/contents.asp

The Working Group believes that appropriate case studies are particularly powerful in understanding and teaching these personal attributes and values in "Disaster Medicine” and specifically invites further case study type input to define the parameters of this important issue.

\section{ISSUE 3 - Personal attributes}

The Working Group recognises that the aspect of personal attributes is complex in an international environment. However, if education programs in "Disaster Medicine" are to be "International", they will need to be informed by the identification of those personal attributes and values deemed to be important in the practice of "Disaster Medicine".

The Working Group seeks input on your reflections and invites case studies on this important issue. 


\section{DEVELOPING AN UNDERLYING SCIENTIFIC FRAMEWORK FOR LINKING THEORY TO PRACTICE IN “DISASTER MEDICINE”.}

The Working Group suggests there is a need to develop scientific framework(s) in "Disaster Medicine" to not only link practice and experience to theory and general principles, but also to underpin sound pedagogy in "Disaster Medicine" education and training programs.

\subsection{ISSUE 4: Creating a scientific framework(s) for "Disaster Medicine”.}

The Working Group seeks to identify the current status of scientific frameworks for "Disaster Medicine" as the basis for later discussion.

It is unlikely that the "science" of "Disaster Medicine" has evolved to the stage of mature theories, however, there are emerging models, frameworks, and, principles which, although not eclectic, are of value in enabling a scientific approach to be taken in "Disaster Medicine".

Using data generated from consultation about issues raised in Part 1, the Working Group believes it may be possible to prepare an embryonic scientific framework for "Disaster Medicine" in terms of theories, models, frameworks or principles, which will, eventually, enable theory to better inform practice. The Working Group believes that this is an important issue to explore and resolve before attempting to develop a framework for possible education and training programs.

A major issue in promoting a more scientific approach is to develop a consensus to go beyond descriptive and anecdotal reporting, to develop a common language and to use more systematic and less arbitrary methods of assessment, evaluation, and presentation in case studies. The recently released publication on "Health Disaster Management: Guidelines for Evaluation and Research in the Utstein Style" Prehospital and Disaster Medicine, 2003:17(Supp 3) http:///pdm.medicine.wisc.edu , may help provide one framework to improve consistency in research and evaluation.

The Working Group is also aware that many individuals and Centres are contributing to this scientific approach and may be willing to enrich the task of the Working Group by sharing their approaches with the Working Group and the international disaster medicine and emergency health community. Some of these approaches may have been published and debated in the international literature and may be identified by the reviews to be conducted in Part 1. However, some may be unpublished, or be evolving and not yet published. For these reasons the Working Group invites additional input which it is hoped will augment discussion at the international meeting in October. 
The Working Group seeks responses to the question, "Do adequate scientific frameworks exist for "Disaster Medicine””?

The Working Group also invites direct input on scientific frameworks for "Disaster Medicine" in terms of theories, models, frameworks, or principles, which may eventually link theory to practice in "Disaster Medicine" and hence provide the cognitive and practice base for underpinning sound pedagogy in "Disaster Medicine" education programs.

The second question related to this issue asks that, if there were no or inadequate frameworks, what activities are required to facilitate the development and promulgation of such frameworks?

Establishing the required frameworks and theories will require co-ordinated development of infrastructure, collaborative ventures and significant resources - all at the international level. However, timing may be kind to the consideration of such proposals by funders.

ISSUE 4.2: Research agenda for "Disaster Medicine”

The Working Group invites input on international strategies to develop a research agenda and priorities for "Disaster Medicine".

The Working Group will liaise with WADEM Research Committee to assist that Committee in its tasks, one of which is the development of a future research and action priorities in "Disaster Medicine".

\section{DEFINING A CONCEPTUAL FRAMEWORK AND THE GENERAL PRINCIPALS TO DEVELOP “INTERNATIONAL STANDARDS AND GUIDELINES ON EDUCATION AND TRAINING FOR THE MULTI-DISCIPLINARY HEALTH RESPONSE TO MAJOR EVENTS WHICH THREATEN THE HEALTH STATUS OF A COMMUNITY”}

The Working Group suggests there is a need to recommend "best practice" and to develop International Standards and Guidelines on education and training based on the science of "Disaster Medicine" and reflecting:

o The changing context of "Disaster Medicine" itself;

o The need for a multi-disciplinary approach, taking into account the different stages before, during, and after an event, and the importance of international exchange and cross border collaboration;

o The needs, vulnerabilities, possibilities, and coping capacities of the local community and people affected; 
o The contemporary influences and drivers, current concepts and principles, and the emerging conceptual frameworks of education and training programs addressing "health response to disasters".

The Working Group suggests there is a need to consider strategies for the implementation of evidence-based standards, quality assurance, and certification of existing and new education and training programs, and, possibly, of practitioners.

\subsection{ISSUE 5: WHERE ARE WE NOW? - Getting to grips with the contemporary concepts and international trends in "Disaster Medicine" education and training.}

\subsubsection{What is the "State-of-the-Art" and what are the international trends in the structure of "Disaster Medicine" education and training programs?}

The Working Group is aware that there are many excellent education and training programs currently offered in "Disaster Medicine" throughout the world. However, it also believes that many of these are not well known on the international stage and that they vary in perspective, duration, quality and recognition. The Working Group is keen to identify and promote appropriate programs in "Disaster Medicine" education and training.

One possible outcome of the Working Group's process is the development of an international list of education and training programs, which, in time, could become a "Register of Approved Education and Training Programs in "Disaster Medicine"”. This item will be further considered in Para 5.2.5.

The Working Group seeks to clarify the current status of global "Disaster Medicine" education and training, and seeks input on:

o The historical context of international "Disaster Medicine" education and training;

o Who is providing "Disaster Medicine" education and training?, eg. undergraduate colleges, universities, professional colleges, collaborative networks etc?;

o What regulations, standards, certification, registration, and specialisation levels exist?;

o What formal course awards are available, ie. initial, graduate, continuing education?;

o What formal short courses are available?;

o What "approved" competency levels have been developed?;

o What community programs are available;

o What is the description of the scope and content of these courses at each level?;

o Which programs demonstrate "best practice" in program structure and could be used as exemplars to assist the further development of leading edge education and training programs in "Disaster Medicine";

o What trends are being demonstrated in the structure of "Disaster Medicine" education and training programs?; and,

o Where are graduates of these "Disaster Medicine" education and training programs currently utilised/employed? 
ISSUE 5.1 - State-of-the-Art - Structure of "Disaster Medicine” education and training programs

The Working Group recognises the identification of the "state-of-the-art" of the structure of education programs in "Disaster Medicine" at the international level as an issue and seeks international input on:

the current structure of education and training programs in "Disaster Medicine”, and are they meeting current needs?;

current programs that are innovative and could be seen as "exemplars" or demonstrate "best practice" in the structure of "Disaster Medicine" education and training; and

where are graduates of "Disaster Medicine" education and training programs currently utilised/employed.?

\subsubsection{What is the current pedagogy demonstrated in the process of "Disaster Medicine” education and training, and what emerging factors may be influencing this pedagogy?}

The Working Group believes that it should identify at an international level, not only the structure of current programs, but also the current pedagogy of "Disaster Medicine" education and training, and what emerging factors may influence this pedagogy?

Is there a pedagogy which characterises "Disaster Medicine” education and training, or do "Disaster Medicine” education and training programs rely on pedagogy from other disciplines?

The Working Group is keen to identify programs which demonstrate "best practice" in pedagogy and could be used as exemplars to assist the further development of leading edge education and training programs in "Disaster Medicine".

The Working Group is aware of generic influences in education and training which may be influencing "Disaster Medicine” education and training; eg.

o The influence of the competency-based movement;

o Case-based and problem-based learning;

o Student-centred and life-long learning;

o On-line and flexible delivery technology;

o Requirement for cognitive skills and professional attributes to be demonstrated;

o Work-place experience requirements within clinical education programs;

o Community-based education;

o Collaborative education and training with dual credentialing;

o An increasing availability of courses in International Health; and,

o Global education. 
However, the Working Group believes that there are also additional "Disaster Medicine" specific influences on education and training but that these are less well recognised and poorly articulated. Some of these specific influences may include:

o Globalisation of "Disaster Medicine";

o Changing scope of "Disaster Medicine";

o The rapid evolution of "emergency preparedness" as a major theme;

o The move from selected/limited to mass education of both professionals and of the community;

o The emergence of multidisciplinary "Disaster Medicine” education and training;

o The introduction of defined systems for eduction in major incident management;

o The emergence of multiple short courses offered by a wide range of providers from government agencies, to traditional education and training providers, to new private providers;

o The need for hands-on experience in actual "Disaster Medicine" situations;

o Use of virtual reality and simulation strategies;

As in Issue 1, the Working Group does not believe that these lists are necessarily exhaustive. However, it believes that there is also "change in the wind" in "Disaster Medicine" education and training and these influences need to be described as a precursor to developing effective educational programs to underpin the effective "multidisciplinary health response to disasters".

The Working Group is keen to share these experiences and to identify "Best Practice" as a step towards the Working Group's objective.

\section{ISSUE 5.2 - Current pedagogy in "Disaster Medicine" education and training programs}

The Working Group has identified the current pedagogy of "Disaster Medicine" education and training as an issue and seeks input on: current pedagogy of "Disaster Medicine" education and training; current programs that are innovative and could be seen as "exemplars" or demonstrate "best practice" in the pedagogy of "Disaster Medicine" education and training; and emerging educational concepts, principles, and frameworks, including generic education and "Disaster Medicine" specific influences, which may impact on this pedagogy?

\subsubsection{Strengths and weaknesses of existing "disaster medicine" education and training programs.}

In seeking input through the previous two issues on current "Disaster Medicine" education and training programs, the Working Group would value your appraisal of the "strengths and weaknesses" of existing "Disaster Medicine” education and training programs. 
This input may be from the perspective of a student, an education provider, or a user/employer of graduates. Specifically, the Working Group is keen to know if current programs are meeting users/employers needs.

The Working Group would be keen to reflect the strengths in its future proposals whilst concurrently attempting to eliminate the weaknesses.

ISSUE 5.3 - Strengths and weaknesses of existing "Disaster Medicine” education and training programs

The Working Group wishes to identify the strengths and weaknesses of existing "Disaster Medicine” education and training programs and seeks input on:

your perceptions of the strengths and weaknesses of existing "Disaster Medicine" education and training programs with suggestions as to how the strengths may be retained, and the weaknesses may be eliminated in future programs.

\subsubsection{What models of "Standards and Guidelines" for education and training exist in kindred fields and may serve as a model for International "Disaster Medicine”?}

The Working Group is aware that throughout the world there are many current situations in which "standards and guidelines" have been prepared in various educational settings. These guidelines are often used by professional organisations to provide guidelines to educational bodies for the conduct of courses and requirements which need to be met if they wish their courses to be accredited by the professional organisation.

One example in the field of prehospital care is the Commission on Accreditation of Allied Health Education Programs which provides "standards and guidelines" for the Emergency Medical Services Professions, http://www.caahep.org/caahep

The Working Group is not suggesting that this is the only or the best example, however, it relates to this field and is an example of what could be achieved in a modified form as an outcome of the Working Group's consultative process.

Throughout the world there is accreditation of medical courses, nursing courses, and other health professionals courses, the models for which may be useful in informing the Working Group’s deliberations.

\section{ISSUE 5.4 - Models of "Standards and Guidelines”}

The Working Group seeks input on examples of models of "standards and guidelines" for educational programs which may be useful to inform the development of such a model for "Disaster Medicine". 


\subsection{ISSUE 6: WHERE DO WE WANT TO GET TO? Identifying contemporary evidence-based education and training standards and guidelines for "Disaster Medicine" education and training programs.}

The Working Group wishes to encourage a medium term vision for "Disaster Medicine” education and training and sets this issue in a 5 year time frame.

\subsection{1 “Disaster Medicine” education and training - a systems approach?}

In considering the future, the Working Group suggests there may be value in exploring a "systems approach" to "Disaster Medicine" education and training. A useful model as an example in a kindred discipline, is that of the EMS Education Agenda for the Future. http://www.nhtsa.dot.gov/people/injury/ems/EdAgenda/final/.

This model designed for the USA EMS system includes the following components:

o Core content;

o Scope of practice model;

o Education standards;

o Certification, (of graduates); and

o Education program accreditation.

The Working Group does not imply that this model is the only model or the best, but uses it as the basis of further discussion.

ISSUE 6.1 - A systems approach to education and training

The Working Group seeks guidance on the usefulness of a systems approach to "Disaster Medicine" education and training.

$>$ would a systems approach be feasible in considering future international programs in "Disaster Medicine" education and Training?; and

if so, what would be the components and relationships in such a model?

\subsubsection{Identifying the levels and scope of practice for "Disaster Medicine"} education and training programs of the future.

In starting to construct a framework to structure future education and training programs in "Disaster Medicine", the Working Group has given initial consideration to the attributes listed above, and outlined in Appendix 3.

Readers are reminded that Appendix 3 is reflective of initial considerations only and is offered for your consideration, debate, and informed input.

In reflecting on this issue, the Working Group asks for your input on:

o How many levels should there be, and what would be their role description?

o What should each level be trained in, ie. "scope of practice"?

o Should the programs be competency based?

o How should the curriculum be structured, eg, core and electives, supervised practice, etc?

o If there is a "core", what is the "Core of the Core" at each level?

o How should the content be delivered?

o Should supervised work experience be a mandatory component at any level? 
o How can appropriate resources be developed and shared globally?

o How can the initiative be monitored and updated?

o Should there be Masters, Specialist and Doctoral levels?

o Should course qualifications be time-limited and subject to compulsory continuing professional development (CPD) and/or re-accreditation?

o Should course instructors be accredited at each level?

o Is it possible to develop collaborative courses, jointly accredited by two or more organisations?

o Is it desirable for external accreditation, possibly internationally, of these courses? At which levels?

The Working Group is aware that there are very successful similar multi-level programs in other disciplines. For example, in emergency cardiac care there is a full suite of articulated community-based and professional courses in Basic and Advanced Life Support. The Working Group would be keen to benefit from lessons learnt by these international programs.

ISSUE 6.2 - Levels and scope of practice for "Disaster Medicine" education and training programs of the future

The Working Group has identified the levels for education and training for "Disaster Medicine" personnel as an issue and seeks input on a medium term view of 5 years:

how many levels should be developed in the scope of "Disaster Medicine", who is the target group and what is the general description (scope of practice) for each level?

$>$ should the Working Group develop standards and guidelines for all levels or just selected levels?

The Working Group believes that while consideration of content in "Disaster Medicine” education and training programs will eventually need to be discussed, the definition of content can be left to a later time after the levels and scope of practice have been resolved.

\subsubsection{What general education principles should be considered to underpin these education and training programs of the future?}

As a preliminary exercise, the Working Group has explored the feasibility of defining a conceptual model for multi-disciplinary "Disaster Medicine" education and training and believes that it will be possible to achieve consensus on the principles of such a conceptual model during the October Conference.

An initial set of attributes or components of a conceptual model are listed below as the basis for further discussion:

o Multi-disciplinary programs

o Vocational focus

o Case or scenario-based framework

o Themed approach

o Core and electives

o Modular approach

o Supervised practical experience

o A competency-based approach

o Competencies within a conceptual framework 
These attributes are further outlined in $\underline{\text { Appendix } 4}$.

ISSUE 6.3 - Principles to underpin "Disaster Medicine” education and training programs of the future

The Working Group has identified the principles of education and training programs for "Disaster Medicine" personnel as an issue and seeks input on:

$>$ general principles which should be considered to underpin these education and training programs of the future.

\subsubsection{Achieving recognition for "Disaster Medicine" practitioners.}

The Working Group is keen to receive input on the emerging trends in the employment and utilisation options for graduates of "Disaster Medicine" education and training programs at various levels. There is a belief that there is an increasing opportunity for "Disaster Medicine" graduates at local, regional, national, and international level. Further, given this issue relates to "the future", where should, and where could, "Disaster Medicine” graduates be employed or utilised in the future?

The WCDEM-13 Education Working Group meeting raised the issue of the level of recognition for "Disaster Medicine" practitioners, at both a local and international levels. At a local level, the importance relates to interacting with kindred professionals and at an international level, relates to recognising the credentials in cross border emergency assistance teams. For these reasons the Working Group seeks your input on this issue.

The Working Group is also aware that in the field of public health medicine, as for other fields of medicine in the Commonwealth countries, the mark of the independent clinical practitioner or Specialist, sometimes referred to as "Consultants", is the "Clinical Fellowship". In public health medicine, there are current negotiations to develop common curricula and mutual recognition at Fellowship level between Australia, New Zealand, Hong Kong and United Kingdom. Also, in hospital based emergency medicine, 11 national emergency medicine post graduate colleges have formed the International Federation for Emergency Medicine which is awarding "Fellowships". The Working Group is also keen to explore this "Fellowship model" for its applicability to the field of "Disaster Medicine”.

Finally, if there are to be international standards and guidelines, which is the task given to the Working Group by WADEM at the request of the international disaster medicine and emergency health community, it raises the sequential question as to which body oversees and maintains these standards and guidelines and if this body should also "approve courses" and credential graduates - this will be addressed in Para 5.3

ISSUE 6.4 - Recognition for “Disaster Medicine” practitioners

The Working Group seeks guidance on:

potential employment/utilisation of "Disaster Medicine" graduates of various levels;

$>$ the adequacy of current recognition of "Disaster Medicine" practitioners; and

$>\quad$ is there a demand for international credentialing of "Disaster Medicine" practitioners? 


\subsubsection{Endorsement of "Disaster Medicine" education and training programs.}

Para. 5.1.1 raised the possibility of developing an international list of "Disaster Medicine" education and training programs which in time could become a "Register of Approved Education and Training Programs in "Disaster Medicine””.

The Working Group sees potential benefits in networking between education providers and in providing the international disaster medicine and emergency health community with a list of available education programs.

The Working Group asks the question as to whether there would be additional benefits in developing a process for external/professional accreditation of "Disaster Medicine" education and training programs with international recognition. As noted previously this process is common in many health disciplines within countries is not common across countries. However, given the global nature of "Disaster Medicine", would it be desirable to have available the external endorsement of "Disaster Medicine” education and training programs. If such endorsement were to be shown to have benefits, it would be reasonable to base endorsement of "Disaster Medicine" education and training programs on the International Standards and Guidelines developed during this process.

\section{ISSUE 6.5 - Endorsement of "Disaster Medicine”} education and training programs

The Working Group seeks guidance on: the pros and cons of developing external/professional endorsement of "Disaster Medicine" education and training programs with international recognition.

\subsubsection{Framework for standards and guidelines on education and training for} the multi-disciplinary health response to major events which threaten the health status of a community.

Given that this consultation process has identified models of standards and guidelines for education and training programs in other situations, and given the Working Group is charged with developing Standards and Guidelines for "Disaster Medicine" education and training programs, the Working Group is keen to receive input on how a framework can be structured for developing standards and guidelines for "Disaster Medicine” education and training programs.

\section{ISSUE 6.6 - Framework for Standards and Guidelines for "Disaster Medicine” education and training}

Given the earlier issue which identified models used in other settings, the Working Group seeks guidance on:

A suitable framework for Standards and Guidelines for "Disaster Medicine” education and training applicable internationally. 


\subsection{ISSUE 7: HOW DO WE GET THERE? - Overcoming barriers to introducing the International Standards and Guidelines.}

\subsubsection{Overcoming Barriers}

The Working Group is committed to achieving measurable outcomes on this project. Of equal importance to the issues previously raised is guidance on an implementation strategy.

The Working Group is well aware that in working at an international level, particularly in a relatively new discipline, there are real and significant barriers to "change". Change is a normal feature of life and of professional development. Although there are general principles guiding change management and implementing innovations, the Working Group is aware that it is likely that there will be specific issues relating to the "Disaster Medicine" field which may act as barriers or limitations to the development and implementation of the International Standards and Guidelines in "Disaster Medicine” education and training.

However, identifying potential barriers although useful, is in itself insufficient without thoughtful and collaborative consideration of appropriate strategies to address effective and efficient implementation.

\section{ISSUE 7.1 - Overcoming barriers}

The Working Group seeks guidance on:

identifying potential barriers to the further development and implementation of International Standards and Guidelines, and what strategies can be examined to overcome these potential barriers?

\subsubsection{Overseeing the development and implementation of the consequent International Standards and Guidelines.}

Of particular interest to the Working Group is a broad based input on whether "international recognition" of education and training programs (Paras 5.1.1 and 5.2.5) and/or of practitioners in "Disaster Medicine" (Para 5.2.4) is desirable or feasible. As noted in Para 5.2.4, there are current moves to improve international recognition, external accreditation, and mutual recognition of academic/professional organisations, educational programs, and practitioners in public health medicine and in emergency medicine. Are there lessons learnt from these disciplines which may be of use to "Disaster Medicine"?

Of critical importance to any consideration on this issue is consideration of effective models, infrastructure, quality assurance, credentialing and resources if this objective is to be achieved. In particular, what role should WADEM have in this process?

\section{ISSUE 7.2 - International oversight}

The Working Group seeks guidance on:

how effective and efficient International oversight can be achieved;

and,

what role should WADEM have in this process? 


\section{Maintaining the Momentum - Improving International Collaborations}

\subsection{ISSUE 8: Exploring the feasibility of an ongoing international, collaborative network of "Centres of Excellence" in "Disaster Medicine" research and/or education.}

The Working Group recognises that systematic "Disaster Medicine” research and evaluation is a relatively new field. However, it also recognises that there are many emerging Centres of Excellence in difference aspects of "Disaster Medicine" research and evaluation, and that some collaboration already exists in this area.

The Working Group believes that effective collaborations will maximise the return on effort in this challenging field and encourages such collaborations. To facilitate this collaboration, the Working Group seeks guidance on establishing an international collaborative network of "Centres of Excellence in "Disaster Medicine" Research and/or Education" and as a first step invites individuals and organisations to register their interest through the Working Group with the intent that this list will be publicised during and after the October international meeting. Developing this International Network can proceed separate, but in parallel, to the development of the International Guidelines and Standards.

\section{ISSUE 8 - International collaboration}

The Working Group seeks guidance on:

$>$ scope, interest in, and methods of establishing a network of collaboration in "Disaster Medicine" research and/or education.

The Working Group also invites individuals and organisations to register their interest in contributing to such a network by forwarding to the Working Group (fa082693@skynet.be) a registration of interest with their contact details in the knowledge that their contact details will be distributed during and following the October international meeting.

7.1 ISSUE 9: What other issues would you like to bring to the attention of the Working Group?

\section{ISSUE 9 - Other issues}

The Working Group recognises that in its preparation of this Issues Paper, it may have overlooked other significant issues and invites you to submit papers on additional issues you see as important to clarify this topic or in addressing the Working Group's terms of reference and ultimate objectives. 


\subsection{WADEM}

Appendix 1

Information about WADEM is provided on the WADEM web site at

http://wadem.medicine.wisc.edu .

\subsection{WADEM Education Committee and Working Group}

This section aims to outline the mandate of the WADEM Education Committee Working Group and its processes in developing this Issues Paper.

\subsection{Mandate from the $13^{\text {th }}$ WCDEM - Melbourne, 2003}

During the World Congress (WCDEM-13) in Melbourne, the Education Working Group had a discussion based on the original question of the need for a Masters Degree in "Disaster Medicine”. A consensus was reached that included a 'WADEM vision statement", two main objectives, an answer to the questions 'why?' and 'why WADEM', an 'Action Plan' and an agreement on the approach. ${ }^{3}$

One of the outcomes of the Melbourne meeting, and endorsed by the closing session of the Congress, was to call a meeting of the Education Working Group within six months of the Melbourne Congress and to prepare for an open, international meeting within 12 months of the Melbourne Congress.

The "Melbourne Statement" also endorsed by the closing session of the Congress also provided direction to WADEM which is being fulfilled by the proposed activities of the Working Group. (Appendix2). The Working Group is responding to the requirements of the Melbourne Congress.

\subsection{Justification}

Justification for WADEM to take an initiative to establish international standards and guidelines with respect to "Disaster Medicine" education and training include:

$>\quad$ There is a need for guidance on best practice and international standards, given the proliferation of all kind of courses and degrees, sometimes with commercial motives;

$>$ WADEM has both the moral/scientific duty and the possibility/capacity to take the lead in this, by centralising the wealth of existing experience and knowledge, and facilitating an open discussion and consensus on best practice; and

$>\quad$ WHO Officers, among others, suggested or informally requested WADEM to provide expert advice with respect to access to educational programs, standardization of curricula and quality assessment of courses.

\subsection{Terms of Reference}

The terms of reference of the Working Group focus on the Working Group taking the necessary steps to:

Investigate and report to the 14th WCDEM in Edinburgh, May 2005, on "fostering the development of international standards and guidelines for the education and training and recognition of disaster and major incident

\footnotetext{
2 "It is the vision of WADEM to foster the international development of guidelines for the education and recognition of disaster and major incident managers and the other members of the health care community".

${ }^{3}$ Cfr. FISHER (J.) and SEYNAEVE (G.J.R.). A Masters in Disaster Management? Melbourne, WADEM

Education Committee, May 9, 2003, 1 pag.
} 
managers and other members of the healthcare community" who contribute to the multi-disciplinary response to major events which actually or potentially threaten the health status of a community. These major events include, but are not necessarily limited to, humanitarian emergencies, natural disasters, public health crises, major incidents and mass gatherings. Note, the underlined section has been added to the original term of reference by the Working Group.

In perusing its mandate, the Working Group raises in this Issues Paper a broader approach than just Degrees in "Disaster Medicine" at the Masters level.

\subsection{Principles}

The Working Group believes that the following principles should be used to help focus on achieving the final objective:

$>\quad$ be ethically based, and include the socio-economic and psychosocial issues;

$>$ focus on the health workforce, both professional and community, as the primary audience;

$>\quad$ include core health perspective elements for other first responders (eg police, fire, local authorities), as well as including core management elements (broader than providing health care) for the health work force;

$>$ focus on education and training, whilst being informed by the "science" of "Disaster Medicine";

$>\quad$ whilst the background would be a conceptual model, it should draw a careful balance between theory and the practical applications; be influenced by recent developments in managing major health events from the civil perspective;

$>\quad$ adopt a modular and scenario-based approach to education and training; and

$>\quad$ structured to acknowledge the dynamic and multidisciplinary nature of this discipline and of the co-disciplines, and also the constantly changing world environment, thereby facilitating and encouraging regular updates to maintain currency of application.

\subsection{Consultation}

Since the Melbourne Congress in May, 2003, the Working Group has had four, two day meetings in each of Brussels, Barcelona, Athens and Edinburgh. This Issues Paper is being circulated widely to the international "Disaster Medicine" and emergency health community. The widest possible input is being actively sought by the Working Group.

Following the October open international Conference, to be held in Brussels, a meeting will be held in early 2005, possibly in the USA, to prepare the final report for the $14^{\text {th }}$ WCDEM in Edinburgh in May 2005.

\subsection{Further information about the Working Group}

Requests for further information about the Working Group should be forwarded electronically by email to Dr Geert Seynaeve as a Chair of the Working Group at the following email: fa082693@skynet.be 


\section{$13^{\text {th }}$ Congress of the World Association of Disaster and Emergency Medicine}

$\square$ Whereas, disasters and emergencies include exceptional events caused by natural hazards and man-made factors, including armed conflict;

Whereas, disasters have global consequences and continue to result in large numbers of potentially preventable deaths and human suffering;

Whereas, disasters create major problems for the public health of populations and the health systems of countries affected by disasters, especially poor countries;

Whereas, there exists a large number of organisations and professional disciplines worldwide that are involved in disaster prevention, preparedness, response, and recovery;

Whereas, there exists a need to develop collaborative relationships between such organizations and disciplines;

Whereas, there is a need for better understanding of the epidemiology of disasters and to rigorously evaluate the effectiveness of preventive and response measures;

Whereas, there currently exist standardized structures for the development of evidence-based indicators and standards for disaster response and for the conduct of structured research (Health Disaster Management: Guidelines for the Evaluation and Research in the Utstein Style);

Whereas, there is a paucity of international systems that independently collate and transfer experiences into improved understanding of these mechanisms.

Thus:

WADEM will focus more of its energies on the public health aspects of disasters and emergencies;

WADEM will contribute to the development and dissemination of knowledge concerning disaster epidemiology, policy, planning, response, recovery, and program evaluation;

WADEM will promote international professional standards and educational programs for persons involved in disaster prevention, preparedness, response, and recovery;

WADEM will facilitate the development of global multidisciplinary collaborative relationships with other organizations and institutions committed to disaster prevention, preparedness, response, and recovery;

WADEM will coordinate a series of consultations to prepare a formal framework of action that will be presented at the 14th World Congress for Disaster and Emergency Medicine to be convened in Edinburgh in 2005. 


\begin{tabular}{|c|c|c|c|c|c|c|c|c|}
\hline \multirow[t]{2}{*}{ Category } & \multicolumn{8}{|c|}{ Attribute } \\
\hline & Target & Description & $\begin{array}{l}\begin{array}{l}\text { Core \& } \\
\text { electives }\end{array} \\
\end{array}$ & Delivery & $\begin{array}{l}\text { Formal } \\
\text { Assessment }\end{array}$ & $\begin{array}{l}\text { Certificate } \\
\text { Issue }\end{array}$ & CPD & $\begin{array}{l}\text { Instructor } \\
\text { level }\end{array}$ \\
\hline Level 1 & Community & $\begin{array}{l}\text { Civilian, community based emergency } \\
\text { preparedness and awareness }\end{array}$ & $\begin{array}{l}\text { Common } \\
\text { core for all, } \\
\text { plus local } \\
\text { needs }\end{array}$ & $\begin{array}{l}\text { Short, didactic, } \\
\text { competency } \\
\text { based, } \\
\text { manageable }\end{array}$ & No & $\begin{array}{l}\text { Certificate } \\
\text { of } \\
\text { Attainment } \\
\text { (time } \\
\text { limited) }\end{array}$ & No & Yes \\
\hline Level 2 & $\begin{array}{l}\text { First responders: } \\
\text { Basic }\end{array}$ & $\begin{array}{l}\text { First contact, primary care providers, all } \\
\text { disciplines and responders. } \\
\text { Categories: } \\
\text { Bronze (provider); Silver (tactical); } \\
\text { Gold (strategic) } \\
\text { Basic general emergency preparedness } \\
\text { (USA model), MIMS (UK model) } \\
\text { Basic discipline, specific fundamentals }\end{array}$ & $\begin{array}{l}\text { Common } \\
\text { core for all, } \\
\text { plus local } \\
\text { needs }\end{array}$ & $\begin{array}{l}\text { Short, didactic, } \\
\text { competency } \\
\text { based, } \\
\text { manageable }\end{array}$ & Yes & $\begin{array}{l}\text { Certificate } \\
\text { (time } \\
\text { limited) }\end{array}$ & Yes & Yes \\
\hline Level 3 & $\begin{array}{l}\text { First responders: } \\
\text { Advanced or } \\
\text { specific } \\
\text { disciplines or } \\
\text { speciality areas }\end{array}$ & $\begin{array}{l}\text { First contact, primary care providers, all } \\
\text { disciplines and responders. } \\
\text { Categories: } \\
\text { Bronze (provider); Silver (tactical); } \\
\text { Gold (strategic) } \\
\text { Advanced general emergency } \\
\text { preparedness (USA model), MIMS (UK } \\
\text { model) } \\
\text { Specific discipline - specialty areas, eg. } \\
\text { CBNR, Communications }\end{array}$ & $\begin{array}{l}\text { Common } \\
\text { core for all, } \\
\text { plus local } \\
\text { needs }\end{array}$ & $\begin{array}{l}\text { Short, didactic, } \\
\text { competency } \\
\text { based, case } \\
\text { related, } \\
\text { manageable }\end{array}$ & Yes & $\begin{array}{l}\text { Advanced } \\
\text { Certificate } \\
\text { (time } \\
\text { limited) }\end{array}$ & Yes & Yes \\
\hline Level 4 & $\begin{array}{l}\text { First responders - } \\
\text { curriculum } \\
\text { enhancement } \\
\text { units for course } \\
\text { awards at } \\
\text { diploma or } \\
\text { Bachelor degree }\end{array}$ & $\begin{array}{l}\text { "Valuated" content and process to enable } \\
\text { Level } 2 / 3 \text { holders to receive academic } \\
\text { credit for their prior studies and undertake } \\
\text { additional related unit(s) in tertiary } \\
\text { courses at an academic or professional } \\
\text { organisation to obtain diploma or } \\
\text { bachelor degree. }\end{array}$ & Yes & $\begin{array}{l}\text { As determined } \\
\text { by specific } \\
\text { academic, } \\
\text { professional } \\
\text { organisations }\end{array}$ & Yes & $\begin{array}{l}\text { Diploma or } \\
\text { Degree. } \\
\text { Issued by } \\
\text { specific } \\
\text { Academic or } \\
\text { professional } \\
\text { organisation }\end{array}$ & Yes & $\begin{array}{l}\text { Academic or } \\
\text { professional } \\
\text { staff }\end{array}$ \\
\hline
\end{tabular}




\begin{tabular}{|c|c|c|c|c|c|c|c|c|}
\hline \multirow[t]{2}{*}{ Category } & \multicolumn{8}{|c|}{ Attribute } \\
\hline & Target & Description & $\begin{array}{l}\text { Core \& } \\
\text { electives }\end{array}$ & Delivery & $\begin{array}{l}\text { Formal } \\
\text { Assessment }\end{array}$ & $\begin{array}{l}\text { Certificate } \\
\text { Issue }\end{array}$ & CPD & $\begin{array}{l}\text { Instructor } \\
\text { level }\end{array}$ \\
\hline Level 5 & $\begin{array}{l}\text { Professional - } \\
\text { Masters degree }\end{array}$ & $\begin{array}{l}\text { Formal education courses at professional } \\
\text { level, ie. Bachelor or Masters for } \\
\text { recognition as “Professional”. } \\
\text { Course curriculum to meet local, national } \\
\text { and international standards. Consider } \\
\text { external accreditation by international } \\
\text { body. }\end{array}$ & $\begin{array}{l}\text { Core of } \\
\text { each of the } \\
\text { three } \\
\text { disciplines } \\
\text { in Para. } \\
9.2 .3 \text {, plus } \\
\text { electives } \\
\text { related to } \\
\text { discipline } \\
\text { and regional } \\
\text { needs. }\end{array}$ & $\begin{array}{l}\text { As determined } \\
\text { by specific } \\
\text { academic or } \\
\text { professional } \\
\text { organisations }\end{array}$ & Yes & $\begin{array}{l}\text { Bachelor or } \\
\text { Masters } \\
\text { Degree. } \\
\text { Issued by } \\
\text { specific } \\
\text { Academic or } \\
\text { professional } \\
\text { organisation }\end{array}$ & Yes & $\begin{array}{l}\text { Academic or } \\
\text { professional } \\
\text { staff }\end{array}$ \\
\hline Level 6 & $\begin{array}{l}\text { Specialist / } \\
\text { Consultant - } \\
\text { Masters plus } \\
\text { practical } \\
\text { experience }\end{array}$ & $\begin{array}{l}\text { For holders of formal education course } \\
\text { award at Masters level to add formal, } \\
\text { supervised, mentored professional } \\
\text { experience in real time "Disaster } \\
\text { Medicine” situations. } \\
\text { Course curriculum to meet local, national } \\
\text { and international standards. Consider } \\
\text { external accreditation by international } \\
\text { body. }\end{array}$ & $\begin{array}{l}\text { Core of } \\
\text { each of the } \\
\text { three } \\
\text { disciplines } \\
\text { in Para. } \\
9.2 .3 \text {, plus } \\
\text { electives } \\
\text { related to } \\
\text { discipline } \\
\text { and regional } \\
\text { needs. }\end{array}$ & $\begin{array}{l}\text { "In the field" } \\
\text { specification of } \\
\text { supervised, } \\
\text { mentored } \\
\text { professional } \\
\text { experience in } \\
\text { real time } \\
\text { "Disaster } \\
\text { Medicine" } \\
\text { situations. }\end{array}$ & Yes & $\begin{array}{l}\text { Formal } \\
\text { course } \\
\text { award, eg. } \\
\text { Fellowship } \\
\text { or specialist } \\
\text { endorsement } \\
\text { as } \\
\text { determined } \\
\text { by specific } \\
\text { Academic or } \\
\text { professional } \\
\text { organisation } \\
\end{array}$ & Yes & $\begin{array}{l}\text { Academic or } \\
\text { professional } \\
\text { staff }\end{array}$ \\
\hline Level 7 & $\begin{array}{l}\text { Researcher, } \\
\text { national leader - } \\
\text { Doctoral }\end{array}$ & $\begin{array}{l}\text { For holders of formal education course } \\
\text { award at Masters level to add formal } \\
\text { training in research and/or delivery and/or } \\
\text { management and/or education at doctoral } \\
\text { level - ie. professional doctorate with } \\
\text { coursework and major thesis. Could be } \\
\text { PhD by major thesis only. } \\
\text { Course curriculum to meet local, national } \\
\text { and international standards. Consider } \\
\text { external accreditation by international } \\
\text { body. }\end{array}$ & $\begin{array}{l}\text { Core of } \\
\text { each of the } \\
\text { three } \\
\text { disciplines } \\
\text { in Para. } \\
9.2 .3 \text {, plus } \\
\text { electives } \\
\text { related to } \\
\text { discipline of } \\
\text { doctoral } \\
\text { studies }\end{array}$ & $\begin{array}{l}\text { As determined } \\
\text { by specific } \\
\text { academic or } \\
\text { professional } \\
\text { organisations }\end{array}$ & Yes & $\begin{array}{l}\text { Doctoral } \\
\text { Degree } \\
\text { Issued by } \\
\text { specific } \\
\text { Academic } \\
\text { organisation }\end{array}$ & No & $\begin{array}{l}\text { Academic or } \\
\text { professional } \\
\text { staff }\end{array}$ \\
\hline
\end{tabular}




\section{General education principles which could be considered to underpin "Disaster Medicine"education and training programs of the future?}

As a preliminary exercise, the Working Group has explored the feasibility of defining a conceptual model for multi-disciplinary "Disaster Medicine” education and training and believes that it will be possible to achieve consensus on the principles of such a conceptual model during the October Conference.

An initial set of attributes or components of a conceptual model are outlined below as the basis for further discussion:

\section{o Multi-disciplinary programs}

The operational context of "Disaster Medicine” is increasingly multi-disciplinary and the Working Group believes that education programs in this field should reflect this operational reality.

\section{$0 \quad$ Vocational focus}

Education and training programs for all levels of “Disaster Medicine” practitioners should be based on a vocational focus with the required underpinning knowledge, understanding, skills and attitudes integrated in the program. The education program should meet, as a minimum, local standards and vocational requirements and also reflect in the international standards which may result from this international consultative process.

\section{o Case or scenario-based framework}

In any education program, educational objectives need to be specified and the various teaching methods need to relate to those objectives. A common teaching method in health professional education is that of "case or scenario-based" education. The Working Group believes that "Disaster Medicine” education lends itself naturally to exploring this methodology as a keystone component of a conceptual framework.

In case or scenario-based models, the selected cases/scenarios:

- integrate the biomedical sciences, health social sciences, clinical sciences, public health sciences, and emergency management standards;

- $\quad$ integrate the required knowledge, skills, and attitudes in a holistic approach;

- facilitate the development of cognitive and management skills in participants;

- facilitate developing the ability to change in the setting of the modern, dynamic, evolving, and integrated community-based emergency response system;

- facilitates the use of concepts/principles in applying the information;

- facilitates a research/evidence-based approach to practice and establishes the foundation for learning from evaluations of major events; and

- lend themselves to be student-centred and suitable for flexible delivery strategies 
Appendix 4 (Cont'd)

\section{o Themed approach}

In structuring education programs, amongst the recent initiatives is the introduction of a themed approach. In such programs the content is arranged in themes which integrate specific disciplines and attempt ot introduce the student to a more integrated, real-life curriculum.

\section{$0 \quad$ Core and electives}

For all of these events there also exists what can be called the 'core knowledge', which is an educational need common to all health workers, and 'elective knowledge' can be added, with more in-depth knowledge and skills, according to professional background and personal interest.

\section{o Modular approach}

The above framework appropriately facilitates a modular approach. By offering international standards and guidelines in a modular way, it will be possible to choose different core units and a number of elective units, depending on existing risks and hazards, the size and possibilities of universities, and individual requirements or preferences.

\section{$0 \quad$ Supervised practical experience}

The very nature of "Disaster Medicine” requires a hands-on approach as reflected in the traditional "tabletop" and field exercises. The Working Group is aware of an increase in complexity and need to demonstrate immediacy of skills in major events which may be a threat to the health of a community. It has thus been suggested that "Disaster Medicine” courses, at least at the more senior level, should include a compulsory period of supervised practical experience over a defined period before receiving course awards. This core requirement would be in addition to the didactic phase of the course.

\section{o A competency-based approach}

The competency movement in education and training is not new, although it has reached greater recognition in the last 10 years or so and has been most strongly linked with developing training in the industrial sector and has been linked to improving productivity of a country in the international arena.

The Columbia University School of Nursing Centre for Health Policy, supported by the Centre's for Disease and Trial and Prevention, and the association of teachers of preventive medicine, have developed competency statements for all public health workers in the setting of bio-terrorism and emergency readiness. These competencies are available through the Columbia University's School of Nursing web site, http://www.nursing.hs.columbia.edu .

Some authors have suggested that the competency approach is reductionist, component driven and inappropriate in professional education programs. These authors argue that this approach is unable to develop higher order cognitive processes such as decision making, a key attribute required of “Disaster Medicine” practitioners. However, other authors argue that it is possible to develop these higher order competencies in the setting of a competency-based approach. 
The Working Group is keen to receive input from the "Disaster Medicine" and emergency health community on the applicability of the competency-based approach for some, or all levels in "Disaster Medicine" education and training at the international level. Of particular interest is whether such competency statements are sufficiently generic to be applicable internationally, or whether they are set within the local context.

\section{o Competencies within a conceptual framework}

The Working Group has attempted to explore the usefulness of the competency approach within the conceptual framework previously outlined.

The competencies required for persons involved in the 'management of events that are a major threat to health' can be situated at the intersection of three main 'disciplines'.

The management of major health incidents includes clinical care, public health and emergency management. The clinical field here is not reduced to skills and competencies belonging to emergency medicine, but includes e.g. psychosocial aspects and contributions from the other health disciplines. This concept can be represented in the following diagram.

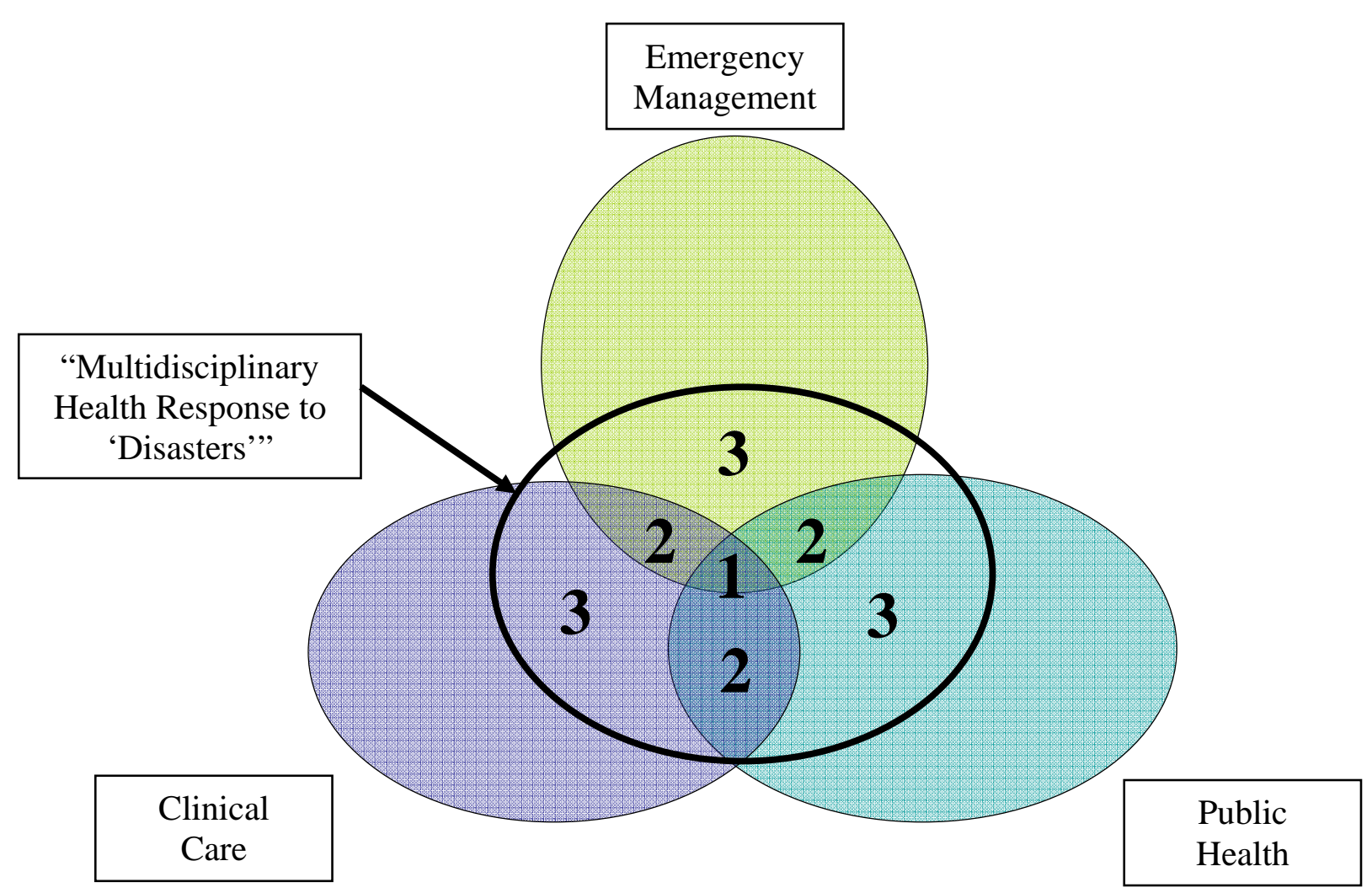

Using the model as outlined previously and modified here, with each circle representing the professional competencies of each of the three disciplines, the "competency package” required in the " Multidisciplinary Health Response to 'Disaster"” can be identified and described at three levels: 


\section{1. within the core, which would be common to all "Disaster" practitioners;}

2. at the interface between two disciplines, which would be common to "Disaster" practitioners from those two disciplines, but not necessarily to those from the third discipline, ie each of the 2's on the above diagram; and

3. within a particular discipline, as additional or updated training specific to that discipline as required for that discipline to contribute effectively in major events that are a threat to the health status of a community, thus each of the " 3 's" in the above diagram would be different and specific to that discipline.

Thus the "Multidisciplinary Health Response to 'Disasters'” is now larger than the original core at the intersection of the three circles and now represents both core and electives roughly depicted by the line at the perimeter of each of the " 3 's". The areas outside the zones 1, 2 and 3 represent the competencies required for practitioners of that discipline to undertake their normal work functions in non-“disaster” situations.

Within each of the main three different fields of knowledge and skills (Clinical, Management, Public Health) there are topics which are part of the standard educational background within each major discipline, and belonging to the daily routine of the health care workers (at the different levels). Other items and issues are extraordinary skills and knowledge which are specific for these extraordinary health incidents. In that discipline, different members of the health community who already have aspects, can be identified which don't belong to one of the overlapping intersections, but for which there is an educational need for updating and/or providing specific specialist teaching. 